\title{
Mass and nutritional quality of upper and lower strata of tropical forages
}

\section{Acúmulo e qualidade de forragem dos estratos superior e inferior de forrageiras tropicais}

\author{
Mailson Poczynek ${ }^{1}$; Mikael Neumann²; Egon Henrique Horst ${ }^{1 *}$; \\ Bruno José Venancio ${ }^{3}$; Danúbia Nogueira Figueira ${ }^{4}$; Milaine Poczynek ${ }^{5}$; \\ Sandra Galbeiro ${ }^{6}$
}

\begin{abstract}
The goal of this work was to evaluate the growth dynamics and chemical characteristics of the upper and lower strata of summer perennial grasses under a four cuts system. The experiment was conducted in a randomized block design, composed of 28 treatments in a factorial arrangement of $7 \times 4$, with four repetitions. The cultivars evaluated were Star Grass, Coast-cross, Tifton 68, Tifton 85, Jiggs, Roxinha and Quicuio. Each cultivar was cut when it reached 95\% light interception. The cultivars Jiggs and Tifton 68 had the highest $(\mathrm{P}<0.05)$ accumulation of dry biomass ha ${ }^{-1}$ during the four cuts, with productions of 21,348 and $21,016 \mathrm{~kg} \mathrm{ha}^{-1}$, respectively. The ash content varied $(\mathrm{P}<0.05)$ among species and times of cutting for both strata. Cellulose contents were significantly different in the upper stratum, with the highest concentrations found in cvs. Quicuio and Tifton 68 (39.12\% and 38.07\%, respectively). We found the highest levels of lignin $(\mathrm{P}<0.05)$, for both strata, in cv. Quicuio. Cultivars Jiggs and Tifton 68 were the most appropriate for a management system of four cuts, displaying good chemical composition and high productivity.
\end{abstract}

Key words: Herbage accumulation. Cynodon. Light interception. Fibrous carbohydrates.

\section{Resumo}

O objetivo deste trabalho foi avaliar a dinâmica de crescimento e as características químicas dos estratos superior e inferior de gramíneas perenes estivais sob sistema de quatro cortes. O experimento foi conduzido em delineamento de blocos casualizados, composto por 28 tratamentos em esquema fatorial $7 \mathrm{x} 4$, com 4 repetições. Foram avaliadas as cultivares Estrela roxa, Coast-cross, Tifton 68, Tifton 85, Jiggs, Hemartrhia roxinha e Quicuio, e o corte de cada cultivar foi estabelecido no momento em que as mesmas alcançaram 95\% de interceptação luminosa. As cvs. Jiggs e Tifton 68 foram responsáveis pelo maior $(\mathrm{P}<0,05)$ acúmulo de massa de forragem seca ha ${ }^{-1}$ durante os quatro cortes, com produções de 21.348 e $21.016 \mathrm{~kg} \mathrm{ha}^{-1}$, respectivamente. $\mathrm{O}$ teor de matéria mineral apontou variações $(\mathrm{P}<0,05)$ entre

\footnotetext{
${ }^{1}$ Médicos Veterinários, Mestres em Agronomia, Universidade Estadual do Centro-Oeste, UNICENTRO, Guarapuava, PR, Brasil. E-mail: mpoczynek@hotmail.com; egonhh@yahoo.com.br

2 Eng ${ }^{\circ}$ Agr ${ }^{\circ}$, Prof. Dr., Nutrição de Ruminantes, UNICENTRO, Guarapuava, PR, Brasil. E-mail neumann.mikael@hotmail.com

3 Discente de Graduação em Medicina Veterinária, UNICENTRO, Guarapuava, PR, Brasil. E-mail: bru.ze.venancio@gmail.com

${ }^{4}$ Médica Veterinária, M.e em Agronomia, Doutoranda em Zootecnia, Universidade Estadual Paulista "Júlio de Mesquita Filho", UNESP, Jaboticabal, SP, Brasil. E-mail: danmedvet@gmail.com

5 Discente de Graduação em Medicina Veterinária, UNICENTRO, Guarapuava, PR, Brasil. E-mail: milainepoc@gmail.com

${ }^{6}$ Zootecnista, Prof ${ }^{a}$ Dr $^{\text {a }}$, Departamento de Zootecnia, Universidade Estadual de Londrina, UEL, Londrina, PR, Brasil. E-mail: sgalbeiro@gmail.com

* Autor para correspondência
} 
as espécies avaliadas e as épocas em que os cortes foram realizados, tanto no estrato superior como no estrato inferior. Houve diferença significativa entre os teores de celulose do estrato superior, onde, as cvs. Quicuio e Tifton 68 foram responsáveis pelas maiores concentrações dessa fração $(39,12 \%$ e $38,07 \%$, respectivamente), e em ambos estratos a cv. Quicuio teve o maior $(\mathrm{P}<0,05)$ nível de lignina. Em manejo de quatro cortes, as cvs. Jiggs e Tifton 68 se mostraram as mais adequadas, pois apresentaram boa composição química e alta produtividade.

Palavras-chave: Acúmulo de forragem. Cynodon. Interceptação luminosa. Carboidratos fibrosos.

\section{Introduction}

Brazilian cattle farming is largely based on extensive and extractive pasture systems (NERES et al., 2012) that have low sustainability, as they fail to optimally use the productive capacity of the pastures, and, as a result, do not achieve maximum animal performance (BARCELLOS et al., 2008). Therefore, it is imperative to adopt sustainable handling practices for forage production, ensuring maintenance of productivity for the longest time possible without harming the ecosystem (NERES et al., 2012). The most common pasture management options for tropical grass pastureland are maintenance fertilizations and stocking rate adjustments (NERES et al., 2012), but the use of rotational grazing is equally important. This grazing management system allows a nutritionally more demanding group of animals to enter the pasture first, to consume the upper stratum of the plants, followed by a less demanding group that consumes the lower stratum, thus optimizing productivity (CARVALHO, 2011).

The morphological and physiological characteristics of the plant affect substrate composition and distribution throughout its structure, influencing the daily consumption and digestibility of a grazed stratum. Animals preferentially graze the upper stratum of the forage, due to its higher concentration in nutrients, and, as they is consume the canopy, the proportion of stem, a more lignified portion, increases. Therefore, it is important to study the nutritional characteristics of different forages compatible with a rotational grazing system, especially as there is less data on plant morphology and strata for tropical than for temperate forage species. With these data we expect to provide valuable input for the selection of forage plants for this type of grazing system in tropical pastures

This work aimed to evaluate growth dynamics and chemical characteristics of the upper and lower strata of summer perennial grasses under a continuous cutting system. With these data we expect to provide valuable input for the selection of forage plants for this type of grazing system in tropical pastures.

\section{Materials and Methods}

Experiments were performed at Universidade Estadual do Centro-Oeste (UNICENTRO), in Guarapuava, PR, Brazil. According to the Kottek classification, the region has a $\mathrm{Cfb}$ climate (humid subtropical mesothermic), with warm summers and mild winters, without defined dry season and with severe frosts. Figure 1 shows the means for maximum and minimum temperatures $\left({ }^{\circ} \mathrm{C}\right)$, relative air humidity ( $\mathrm{RH} \%$ ), insolation in hours day ${ }^{-1}$, and monthly rainfall in $\mathrm{mm} \mathrm{month}^{-1}$, during the experimental period.

The experiment was conducted in a randomized block design, composed of 28 treatments in a factorial arrangement of $7 \times 4$, with 4 repetitions. We tested five summer perennial grasses of genus Cynodon, Cynodon nlemfuensis Vanderyst cv. Star Grass, Cynodon dactylon (L.) Pers. cv. Coast-cross 1; Cynodon nlemfuensis Vanderyst cv. Tifton-68; Cynodon ssp. cv. Tifton-85 and Cynodon dactylon sp. cv. Jiggs; one of genus Hemarthria (Hemarthria altissima cv. Roxinha), and one of genus Penissetum (Penissetum clandestinum cv. Quicuio), in a system of four successive cuts. 
The soil of the experimental area was a typical brown latosol (POTT et al., 2007). Prior to cultivation, it had the following chemical characteristics (profile from 0 to $20 \mathrm{~cm}$ ): $\mathrm{pH} \mathrm{CaCl}_{2}$
0.01M: 4.6; P: $2.0 \mathrm{mg} \mathrm{L}^{-1} ; \mathrm{K}^{+}: 0.43 \mathrm{cmol}_{\mathrm{c}} \mathrm{L}^{-1} ; \mathrm{MO}$ : $34.9 \mathrm{~g} \mathrm{~L}^{-1} ; \mathrm{Al}^{3+}: 0.0 \mathrm{cmol}_{\mathrm{c}} \mathrm{L}^{-1} ; \mathrm{H}^{+}+\mathrm{Al}^{3+}: 6.4 \mathrm{cmol}_{\mathrm{c}}$ $\mathrm{L}^{-1} ; \mathrm{Ca}^{2+}: 2.5 \mathrm{cmol}_{\mathrm{c}} \mathrm{L}^{-1} ; \mathrm{Mg}^{2+}: 2.8 \mathrm{cmol}_{\mathrm{c}} \mathrm{L}^{-1}$ and base saturation (V\%): $48.9 \%$.

Figure 1. Monthly means for maximum and minimum temperatures $\left({ }^{\circ} \mathrm{C}\right)$, relative air humidity $(\mathrm{RH}, \%)$, insolation (hours.day ${ }^{-1}$ ), and rainfall $(\mathrm{mm})$ during the experimental period. Source: SIMEPAR/UNICENTRO weather station, Guarapuava, PR, Brazil.

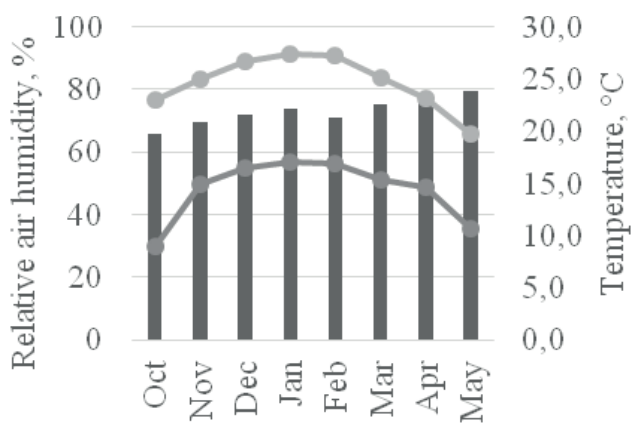

$\longrightarrow$ RH $\longrightarrow$ Max. Temp. $\longrightarrow$ Min. Temp

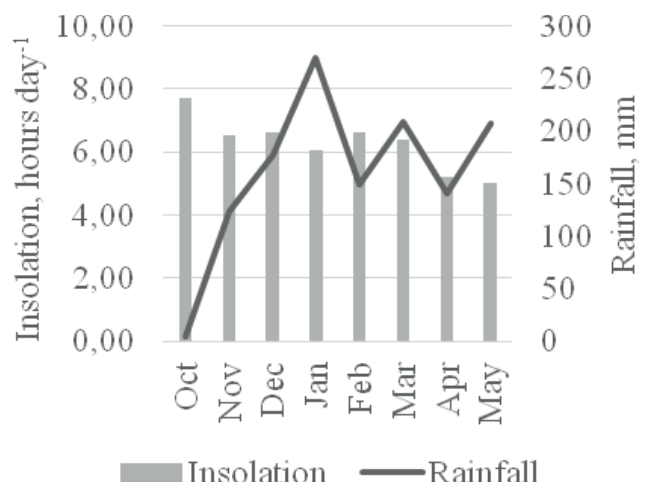

The central part of $2.25 \mathrm{~m}^{2}(1.5 \times 1.5 \mathrm{~m})$ was used for data collection.

All cultivars were cut to a uniform height of 0.12 $\mathrm{m}$ from the ground on November 11, 2013, using a sickle. Then, each cultivar was cut when it reached 95\% light interception (LI), and measurements were taken (assessment cuttings). LI was estimated through photosynthetically active radiation (PAR), which was measured by an AccuPAR LP-80 linear digital ceptometer (Decagon, Devices). Table 1 shows the time interval between cuts and cycles in days, for each evaluated cultivar.

Table 1. Time interval between cuts and cycles in days for each perennial cultivar.

\begin{tabular}{lccccc}
\hline \multirow{2}{*}{ Forage } & \multicolumn{4}{c}{ Time interval between cuts (days) } & \multirow{2}{*}{ Cycle (days) } \\
\cline { 2 - 5 } & $1^{\text {st }}$ cut & $2^{\text {nd }}$ cut & $3^{\text {rd }}$ cut & $4^{\text {th }}$ cut & \\
\hline Star Grass & 34 & 39 & 49 & 70 & 192 \\
Coast-cross & 33 & 40 & 47 & 66 & 186 \\
Tifton 68 & 33 & 37 & 50 & 46 & 166 \\
Tifton 85 & 35 & 35 & 31 & 35 & 136 \\
Jiggs & 35 & 38 & 47 & 44 & 164 \\
Roxinha limpogras & 33 & 44 & 59 & 68 & 204 \\
Quicuio & 55 & 36 & 45 & 68 & 204 \\
\hline
\end{tabular}


Canopy height was measured immediately before and after each assessment cutting (BIRCHAM, 1981). After cutting the grass, we measured the daily and total accumulation of forage biomass in $\mathrm{ha}^{-1}$. A homogeneous subsample of each parcel was collected, immediately taken to the laboratory and divided in upper (segment superior to $0.12 \mathrm{~m}$ ) and lower stratum (segment between 0 and $0.12 \mathrm{~m}$ ). All samples were pre-dried at $55^{\circ} \mathrm{C}$ in a greenhouse with forced ventilation until they reached a constant weight (AOAC, 1995). They were then ground using a "Wiley"-type grinder with a $1 \mathrm{~mm}$ sieve, to determine the following parameters: neutral detergent insoluble fiber content (VAN SOEST et al., 1991), and acid detergent insoluble fiber (ADF) and acid detergent lignin (GOERING; VAN SOEST, 1970). Hemicellulose (HEM) content was calculated by subtracting ADF from NDF, and cellulose (CEL) content by subtracting lignin from ADF. Total digestible nutrient content (TDN, \%) was calculated by the equation $[\mathrm{TDN}=87.84-(0.70$ x ADF)] (BOLSEN et al., 1996), while Net Energy for Lactation was obtained from the equation NEL $=0.0245 \times \mathrm{TDN}-0.12$ (MOE; TYRREL, 1976).

Shapiro-Wilk and Bartlett tests were used, respectively, to verify the normality and variance homogeneity of the data. Once these assumptions were verified, an $\mathrm{F}$ test with 5\% confidence probability was applied by performing variance analysis (ANOVA) followed by Tukey's multiple comparison test (for means) with a 5\% significance level, using the SAS software (SAS INSTITUTE, 1993).

\section{Results and Discussion}

Table 2 shows canopy height and daily accumulation of dry biomass at each cut, as well as total accumulation of dry biomass in the four cuts. Significant differences $(\mathrm{P}<0.05)$ in canopy height and daily accumulation of dry biomass (in kg.ha-1) were detected among different forage species and harvest periods.

Table 2. Canopy height by the time of the cut, and daily and total accumulation of dry biomass for the perennial cultivars, for each cut.

\begin{tabular}{|c|c|c|c|c|c|}
\hline \multirow{2}{*}{ Forage } & $1^{\text {st }}$ cut & $2^{\text {nd }}$ cut & $3^{\text {rd }}$ cut & $4^{\text {th }}$ cut & \\
\hline & \multicolumn{4}{|c|}{ Canopy height, $\mathrm{cm}$} & Average \\
\hline Star Grass & $45.8 \mathrm{~b}$ & $50.5 \mathrm{a}$ & $47.0 \mathrm{a}$ & $42.0 \mathrm{ab}$ & $46.3 \mathrm{a}$ \\
\hline Coast-cross & $38.3 \mathrm{c}$ & $45.3 \mathrm{abc}$ & $41.3 \mathrm{bc}$ & $37.0 \mathrm{c}$ & $40.5 \mathrm{~b}$ \\
\hline Tifton 68 & $51.0 \mathrm{a}$ & $47.5 \mathrm{ab}$ & $50.0 \mathrm{a}$ & $43.8 \mathrm{a}$ & $48.3 \mathrm{a}$ \\
\hline Tifton 85 & $39.3 \mathrm{c}$ & $43.0 \mathrm{c}$ & $36.5 \mathrm{~d}$ & $37.8 \mathrm{c}$ & $39.1 \mathrm{~b}$ \\
\hline Jiggs & $41.8 \mathrm{bc}$ & $44.0 \mathrm{bc}$ & $42.5 \mathrm{~b}$ & $38.8 \mathrm{bc}$ & $41.8 \mathrm{~b}$ \\
\hline Roxinha limpogras & $45.3 \mathrm{~b}$ & $44.3 \mathrm{bc}$ & $47.3 \mathrm{a}$ & $34.8 \mathrm{c}$ & $42.9 \mathrm{~b}$ \\
\hline Quicuio & $28.8 \mathrm{~d}$ & $31.5 \mathrm{~d}$ & $37.5 \mathrm{~cd}$ & $37.5 \mathrm{c}$ & $33.8 \mathrm{c}$ \\
\hline \multirow[t]{2}{*}{ Average } & $41.4 \mathrm{AB}$ & $43.7 \mathrm{~A}$ & $43.3 \mathrm{~A}$ & $38.8 \mathrm{~B}$ & \\
\hline & \multicolumn{4}{|c|}{ Daily accumulation of dry biomass, $\mathrm{kg}$ ha day ${ }^{-1}$} & Total, $\mathrm{kg} \mathrm{ha}^{-{ }^{*}}$ \\
\hline Star Grass & $125.5 \mathrm{~cd}$ & $87.0 \mathrm{~cd}$ & $108.7 \mathrm{~cd}$ & $69.0 \mathrm{~b}$ & $17327 \mathrm{bc}$ \\
\hline Coast-cross & $146.6 \mathrm{~b}$ & $92.2 \mathrm{bcd}$ & $83.8 \mathrm{de}$ & $50.7 \mathrm{bc}$ & 15812 bc \\
\hline Tifton 68 & $205.4 \mathrm{a}$ & $98.5 \mathrm{abc}$ & $125.1 \mathrm{bc}$ & $94.3 \mathrm{a}$ & $21016 \mathrm{a}$ \\
\hline Tifton 85 & $152.0 \mathrm{bc}$ & $112.4 \mathrm{ab}$ & $155.8 \mathrm{a}$ & $94.4 \mathrm{a}$ & $17418 \mathrm{~b}$ \\
\hline Jiggs & $164.3 \mathrm{~b}$ & $121.2 \mathrm{a}$ & $134.7 \mathrm{ab}$ & $105.9 \mathrm{a}$ & $21348 \mathrm{a}$ \\
\hline Roxinha limpogras & $110.5 \mathrm{~d}$ & $71.1 \mathrm{~d}$ & $77.7 \mathrm{e}$ & $32.1 \mathrm{c}$ & $13548 \mathrm{~d}$ \\
\hline Quicuio & $84.4 \mathrm{e}$ & $94.3 \mathrm{bcd}$ & 94.4 de & $50.0 \mathrm{bc}$ & $15686 \mathrm{c}$ \\
\hline Average & $139.7 \mathrm{~A}$ & $96.7 \mathrm{C}$ & $111.5 \mathrm{~B}$ & $70.9 \mathrm{D}$ & \\
\hline
\end{tabular}

Averages followed by different column lowercase letters, and different row uppercase letters, are significantly different according to Tukey's test with a $5 \%$ significance level.

*Total dry biomass accumulated per ha, relative to the four cuts. 
Cultivars Jiggs and Tifton 68 accumulated the most $(\mathrm{P}<0.05)$ dry biomass accumulation over the four cuts, 21,348 and 21,016 kg.ha- ${ }^{-1}$, respectively. These cultivars are able to store a carbohydrate reserve in their stolons, allowing for a fast and vigorous sprouting even in harsh conditions (PEDREIRA; SILVA, 2009). These results are in agreement with previous studies that demonstrated high productivity in cv. Tifton 68 (BURTON; MONSON, 1993), and in cv. Jiggs, with the latter being found comparable to cv. Tifton 68 and to cv. Tifton 85 (CARVALHO, 2011). Furthermore, cv. Tifton 68 seems to be more resistant to cold than cv. Coast-cross (BURTON; MONSON, 1993). Thus, the local climate, with average minimum temperatures as low as $9{ }^{\circ} \mathrm{C}$, may be a reason why cv. Coast-cross the a total productivity $5,204 \mathrm{~kg} \mathrm{ha}^{-1}$ lower than cv. Tifton 68. Hemarthria altissima cv. Roxinha had the lowest $(\mathrm{P}<0.05)$ total accumulation of dry biomass, $13,548 \mathrm{~kg} \cdot \mathrm{ha}^{-1}$, in agreement with a previous study that found Cynodon cultivars to have the highest productivity compared with other grass genera (SOARES FILHO et al., 2002). Nevertheless, productivity under our conditions was still greater than what Carvalho (2011) previously reported for Hemarthria altissima cv. Roxinha $\left(12,010 \mathrm{~kg} \mathrm{ha}^{-1}\right)$.

Cultivar Tifton 68 achieved the highest mean canopy height $(48.3 \mathrm{~cm})$, while cv. Quicuio achieved the lowest $(33.8 \mathrm{~cm})$. These data directly affected the results of productivity per stratum, reported on table 3 , as only the portion above $24 \mathrm{~cm}$ of the ground level was considered for evaluating the upper stratum. Thus, cv. Quicuio had, on average, the largest $(\mathrm{P}<0.05)$ proportion of dry biomass in the lower stratum, at $51.35 \%$, and the lowest proportion in the upper stratum, for which cv. Quicuio stands out negatively, as the lower stratum is more fibrous and has less soluble carbohydrates than the upper stratum. Conversely, cv. Tifton 68 was among the cultivars with the largest proportion of dry biomass in the more digestible upper stratum $(68.12 \%)$, after cvs. Star Grass (71.05\%) and Coast-cross (69.03\%), and just above cv. Jiggs (65.51\%).

Table 3. Proportion of forage mass (\%) for upper and lower strata, respectively, for each cut.

\begin{tabular}{|c|c|c|c|c|c|}
\hline \multirow{2}{*}{ Forage } & $1^{\text {st }}$ cut & $2^{\text {nd }}$ cut & $3^{\text {rd }}$ cut & $4^{\text {th }}$ cut & Average \\
\hline & \multicolumn{5}{|c|}{ Proportion of upper stratum in the plant, $\%$} \\
\hline Star Grass & $70.35 \mathrm{a}$ & $72.67 \mathrm{a}$ & $71.40 \mathrm{a}$ & $69.77 \mathrm{a}$ & $71.05 \mathrm{a}$ \\
\hline Coast-cross & $73.18 \mathrm{a}$ & $69.43 \mathrm{ab}$ & $66.13 \mathrm{ab}$ & $67.37 \mathrm{a}$ & $69.03 \mathrm{a}$ \\
\hline Tifton 68 & $69.35 \mathrm{ab}$ & $64.33 \mathrm{bc}$ & $70.18 \mathrm{a}$ & $68.65 \mathrm{a}$ & $68.12 \mathrm{a}$ \\
\hline Tifton 85 & $58.28 \mathrm{c}$ & $58.32 \mathrm{c}$ & $53.90 \mathrm{~d}$ & $54.45 \mathrm{~b}$ & $56.24 \mathrm{~b}$ \\
\hline Jiggs & $62.32 \mathrm{bc}$ & $66.98 \mathrm{~b}$ & $65.66 \mathrm{ab}$ & $67.07 \mathrm{a}$ & $65.51 \mathrm{a}$ \\
\hline Roxinha limpogras & $65.67 \mathrm{abc}$ & $57.98 \mathrm{c}$ & $56.79 \mathrm{c}$ & $33.59 \mathrm{~d}$ & $53.51 \mathrm{~b}$ \\
\hline Quicuio & $43.76 \mathrm{~d}$ & $48.11 \mathrm{~d}$ & $59.80 \mathrm{~b}$ & $42.95 \mathrm{c}$ & $48.65 \mathrm{c}$ \\
\hline \multirow[t]{2}{*}{ Average } & $63.27 \mathrm{~A}$ & $62.54 \mathrm{~A}$ & $57.69 \mathrm{~B}$ & $50.00 \mathrm{C}$ & \\
\hline & \multicolumn{5}{|c|}{ Proportion of lower stratum in the plant, $\%$} \\
\hline Star Grass & $29.65 \mathrm{c}$ & $27.33 \mathrm{~d}$ & $28.60 \mathrm{c}$ & $30.23 \mathrm{~d}$ & $28.95 \mathrm{c}$ \\
\hline Coast-cross & $26.82 \mathrm{c}$ & $30.16 \mathrm{~cd}$ & $32.37 \mathrm{bc}$ & $32.63 \mathrm{~d}$ & $30.50 \mathrm{c}$ \\
\hline Tifton 68 & $30.65 \mathrm{c}$ & $35.67 \mathrm{bc}$ & $29.82 \mathrm{c}$ & $31.35 \mathrm{~d}$ & $31.88 \mathrm{c}$ \\
\hline Tifton 85 & $41.72 \mathrm{~b}$ & $41.68 \mathrm{~b}$ & $46.10 \mathrm{a}$ & $45.55 \mathrm{c}$ & $43.76 \mathrm{~b}$ \\
\hline Jiggs & $37.68 \mathrm{bc}$ & $33.02 \mathrm{~cd}$ & $34.34 \mathrm{bc}$ & $32.93 \mathrm{~d}$ & $34.39 \mathrm{c}$ \\
\hline Roxinha limpogras & $34.33 \mathrm{bc}$ & $42.02 \mathrm{~b}$ & $43.21 \mathrm{a}$ & $71.25 \mathrm{a}$ & $47.70 \mathrm{ab}$ \\
\hline Quicuio & $56.24 \mathrm{a}$ & $51.89 \mathrm{a}$ & $40.20 \mathrm{ab}$ & $57.05 \mathrm{~b}$ & $51.35 \mathrm{a}$ \\
\hline Average & $36.73 \mathrm{~B}$ & $37.40 \mathrm{~B}$ & $36.38 \mathrm{~B}$ & $43.00 \mathrm{~A}$ & \\
\hline
\end{tabular}

Averages followed by different column lowercase letters, and different row uppercase letters, are significantly different (Tukey, $\mathrm{p}<0.05$ ). 
Averaging all cultivars, the proportion of dry biomass in the upper stratum tended to decrease from the first to the fourth cut, with significant differences observed for the third and fourth cuts $(\mathrm{P}>0.05)$. We failed to observe the same trend, however, for the proportion dry biomass in the lower stratum, as the third cut was numerically inferior to the second, and the first three cuts were not different ( $P>0.05$ ). According to Benincasa (2003), grasses tend to increase the proportion of lower stratum as the cycle progresses. They also modify the profile of leafs, stem, inflorescence and senescent material (aspects that were observed but not reported in this study).

Ash content varied $(\mathrm{P}<0.05)$ both among cultivars and among cuttings, for both strata
(Table 4). Cultivar Tifton 85 had the highest ash content, when averaged across all cuttings, for both upper and lower strata, followed by cv. Tifton 68. According to Carvalho (2011), the bromatological qualities of $\mathrm{cv}$. Tifton 85 result from genetic improvement, which endowed it with a long production period and a high level of responsiveness to mineral fertilization. Regarding the cuttings, the average ash content of all cultivars showed a continuous decreasing tendency in the upper stratum, and a significant decrease $(\mathrm{P}<0.05)$ between the first two and last two cuts in the lower stratum. According to Taiz e Zeiger et al. (2013), no isolated factor influences as much forage quality as the plant developmental stage, as tissue lignification occurs as the plant cycle progresses, diluting the constituent fractions.

Table 4. Ash content (\%) for the DM of the upper and lower strata of the perennial cultivars, for each cut.

\begin{tabular}{|c|c|c|c|c|c|}
\hline \multirow{2}{*}{ Forage } & $1^{\text {st }}$ cut & $2^{\text {nd }}$ cut & $3^{\text {rd }}$ cut & $4^{\text {th }}$ cut & Average \\
\hline & \multicolumn{5}{|c|}{ MM content in the upper stratum, $\%$} \\
\hline Star Grass & $4.96 \mathrm{~b}$ & $5.16 \mathrm{~b}$ & $4.03 \mathrm{c}$ & $4.04 \mathrm{~cd}$ & $4.55 \mathrm{c}$ \\
\hline Coast-cross & $5.85 \mathrm{a}$ & $4.96 \mathrm{c}$ & $4.81 \mathrm{~b}$ & $3.83 \mathrm{~d}$ & $4.86 \mathrm{bc}$ \\
\hline Tifton 68 & $5.84 \mathrm{a}$ & $5.68 \mathrm{a}$ & $5.37 \mathrm{a}$ & $4.36 \mathrm{c}$ & $5.31 \mathrm{~b}$ \\
\hline Tifton 85 & $5.92 \mathrm{a}$ & $5.94 \mathrm{a}$ & $5.26 \mathrm{a}$ & $7.07 \mathrm{a}$ & $6.05 \mathrm{a}$ \\
\hline Jiggs & $5.31 \mathrm{ab}$ & $5.21 \mathrm{ab}$ & $4.15 \mathrm{c}$ & $4.97 \mathrm{~b}$ & $4.91 \mathrm{bc}$ \\
\hline Roxinha limpogras & $4.36 \mathrm{bc}$ & $4.59 \mathrm{c}$ & $4.66 \mathrm{~b}$ & $4.19 \mathrm{c}$ & $4.45 \mathrm{c}$ \\
\hline Quicuio & $3.76 \mathrm{c}$ & $4.46 \mathrm{c}$ & $4.96 \mathrm{~b}$ & $4.18 \mathrm{c}$ & $4.35 \mathrm{c}$ \\
\hline \multirow[t]{2}{*}{ Average } & $5.15 \mathrm{~A}$ & $5.14 \mathrm{~A}$ & $4.75 \mathrm{AB}$ & $4.66 \mathrm{~B}$ & \\
\hline & \multicolumn{5}{|c|}{ MM content in the lower stratum, $\%$} \\
\hline Star Grass & $5.71 \mathrm{~b}$ & $5.41 \mathrm{c}$ & $3.40 \mathrm{~d}$ & $4.45 \mathrm{~b}$ & $4.74 \mathrm{c}$ \\
\hline Coast-cross & $6.14 \mathrm{a}$ & $5.43 \mathrm{c}$ & $4.17 \mathrm{c}$ & $3.60 \mathrm{c}$ & $4.83 \mathrm{bc}$ \\
\hline Tifton 68 & $6.36 \mathrm{a}$ & $6.31 \mathrm{~b}$ & $4.80 \mathrm{~b}$ & $4.61 \mathrm{~b}$ & $5.52 \mathrm{~b}$ \\
\hline Tifton 85 & $6.45 \mathrm{a}$ & $7.31 \mathrm{a}$ & $6.40 \mathrm{a}$ & $8.41 \mathrm{a}$ & $7.14 \mathrm{a}$ \\
\hline Jiggs & $6.13 \mathrm{a}$ & $5.38 \mathrm{c}$ & $4.11 \mathrm{c}$ & $4.24 \mathrm{bc}$ & $4.96 \mathrm{bc}$ \\
\hline Roxinha limpogras & $4.61 \mathrm{c}$ & $4.40 \mathrm{~d}$ & $4.58 \mathrm{bc}$ & $4.82 \mathrm{~b}$ & $4.60 \mathrm{c}$ \\
\hline Quicuio & $3.68 \mathrm{~d}$ & $4.68 \mathrm{~d}$ & $4.36 \mathrm{bc}$ & $4.56 \mathrm{~b}$ & $4.32 \mathrm{c}$ \\
\hline Average & $5.58 \mathrm{~A}$ & $5.56 \mathrm{~A}$ & $4.55 \mathrm{~B}$ & $4.95 \mathrm{~B}$ & \\
\hline
\end{tabular}

Averages followed by different column lowercase letters, and different row uppercase letters, are significantly different (Tukey, $\mathrm{p}<0.05)$.

Table 5 shows the DM content, TDN content and net energy for lactation in the upper stratum, for each cut. Averaging across cuts, cv. Quicuio's upper stratum had the highest $(\mathrm{P}<0.05)$ percentage of 
DM accumulated in the plant (29.1\%). In contrast, cv. Roxinha had the lowest DM content (20.5\%). Averaging across cultivars, however, DM content behaved erratically in relation to the sequence of cuts. Nevertheless, the highest DM content came from the fourth cut $(25.9 \%)$. This characteristic is specific to the cut system that was used, where as the maturation progresses the tillers decrease in number and grow vertically (SILVA et al., 2011). At times, this delays reaching the $95 \%$ light interception that is used as basis for cutting, allowing the plant to add DM to its composition.

Table 5. DM content, total digestible nutrient (TDN) content and net energy for lactation for the upper stratum of the perennial cultivars, for each cut.

\begin{tabular}{|c|c|c|c|c|c|}
\hline \multirow{2}{*}{ Forage } & $1^{\text {st }}$ cut & $2^{\text {nd }}$ cut & $3^{\text {rd }}$ cut & $4^{\text {th }}$ cut & Average \\
\hline & \multicolumn{5}{|c|}{$\mathrm{DM}, \%$} \\
\hline Star Grass & $23.0 \mathrm{de}$ & $22.5 \mathrm{abc}$ & $24.4 \mathrm{ab}$ & $28.2 \mathrm{~b}$ & $21.7 \mathrm{~d}$ \\
\hline Coast-cross & $25.0 \mathrm{~cd}$ & $21.8 \mathrm{abc}$ & $22.4 \mathrm{~b}$ & $27.0 \mathrm{bcd}$ & $24.1 \mathrm{~b}$ \\
\hline Tifton 68 & $28.6 \mathrm{ab}$ & $20.6 \mathrm{c}$ & $24.4 \mathrm{ab}$ & $24.6 \mathrm{~cd}$ & $24.6 \mathrm{ab}$ \\
\hline Tifton 85 & $25.5 \mathrm{~cd}$ & $23.8 \mathrm{ab}$ & $25.9 \mathrm{a}$ & 20.9 e & $24.0 \mathrm{~b}$ \\
\hline Jiggs & $26.2 \mathrm{bc}$ & $24.3 \mathrm{a}$ & $25.4 \mathrm{a}$ & $27.2 \mathrm{bc}$ & $25.8 \mathrm{a}$ \\
\hline Roxinha limpogras & $20.5 \mathrm{e}$ & $22.7 \mathrm{abc}$ & $22.3 \mathrm{~b}$ & $31.2 \mathrm{a}$ & $23.7 \mathrm{~b}$ \\
\hline Quicuio & $29.1 \mathrm{a}$ & $21.6 \mathrm{bc}$ & $25.9 \mathrm{a}$ & $24.3 \mathrm{~d}$ & $22.7 \mathrm{~cd}$ \\
\hline \multirow[t]{2}{*}{ Average } & $25.4 \mathrm{~A}$ & $22.5 \mathrm{~B}$ & $23.0 \mathrm{~B}$ & $25.9 \mathrm{~A}$ & \\
\hline & \multicolumn{5}{|c|}{ TDN, \% } \\
\hline Star Grass & $64.44 \mathrm{~b}$ & $66.09 \mathrm{~b}$ & $66.37 \mathrm{a}$ & $66.92 \mathrm{a}$ & $65.96 \mathrm{a}$ \\
\hline Coast-cross & $66.33 \mathrm{a}$ & $63.45 \mathrm{bc}$ & $64.70 \mathrm{c}$ & $65.83 \mathrm{ab}$ & $65.07 \mathrm{ab}$ \\
\hline Tifton 68 & $66.47 \mathrm{a}$ & $65.43 \mathrm{bc}$ & $65.39 \mathrm{~b}$ & $64.18 \mathrm{c}$ & $65.37 \mathrm{ab}$ \\
\hline Tifton 85 & $65.53 \mathrm{ab}$ & $66.11 \mathrm{~b}$ & $66.36 \mathrm{a}$ & $62.15 \mathrm{~d}$ & $65.04 \mathrm{ab}$ \\
\hline Jiggs & $65.12 \mathrm{ab}$ & $65.46 \mathrm{bc}$ & $65.32 \mathrm{c}$ & $65.12 \mathrm{bc}$ & $65.26 \mathrm{ab}$ \\
\hline Roxinha limpogras & $63.56 \mathrm{c}$ & $62.49 \mathrm{c}$ & $64.60 \mathrm{c}$ & $64.57 \mathrm{c}$ & $63.80 \mathrm{~b}$ \\
\hline Quicuio & $64.09 \mathrm{~b}$ & $68.66 \mathrm{a}$ & $65.52 \mathrm{~b}$ & $65.47 \mathrm{bc}$ & $65.94 \mathrm{a}$ \\
\hline \multirow[t]{2}{*}{ Average } & $65.08 \mathrm{~A}$ & $65.38 \mathrm{~A}$ & $65.47 \mathrm{~A}$ & $64.89 \mathrm{~A}$ & \\
\hline & \multicolumn{5}{|c|}{ Net Energy for Lactation, Mcal kg of $\mathrm{DM}^{-1}$} \\
\hline Star Grass & $1.46 \mathrm{~b}$ & $1.50 \mathrm{~b}$ & $1.51 \mathrm{a}$ & $1.52 \mathrm{a}$ & $1.50 \mathrm{a}$ \\
\hline Coast-cross & $1.51 \mathrm{a}$ & $1.44 \mathrm{bc}$ & $1.47 \mathrm{c}$ & $1.49 \mathrm{ab}$ & $1.47 \mathrm{ab}$ \\
\hline Tifton 68 & $1.51 \mathrm{a}$ & $1.48 \mathrm{bc}$ & $1.48 \mathrm{~b}$ & $1.45 \mathrm{c}$ & $1.48 \mathrm{ab}$ \\
\hline Tifton 85 & $1.49 \mathrm{ab}$ & $1.50 \mathrm{~b}$ & $1.50 \mathrm{a}$ & $1.40 \mathrm{~d}$ & $1.47 \mathrm{ab}$ \\
\hline Jiggs & $1.48 \mathrm{ab}$ & $1.49 \mathrm{~b}$ & $148 \mathrm{c}$ & $1.48 \mathrm{bc}$ & $1.48 \mathrm{ab}$ \\
\hline Roxinha limpogras & $1.44 \mathrm{c}$ & $1.41 \mathrm{c}$ & $1.46 \mathrm{c}$ & $1.46 \mathrm{c}$ & $1.44 \mathrm{~b}$ \\
\hline Quicuio & $1.45 \mathrm{bc}$ & $1.56 \mathrm{a}$ & $1.49 \mathrm{~b}$ & $1.49 \mathrm{bc}$ & $1.50 \mathrm{a}$ \\
\hline Average & $1.47 \mathrm{~A}$ & $1.48 \mathrm{~A}$ & $1.48 \mathrm{~A}$ & $1.47 \mathrm{~A}$ & \\
\hline
\end{tabular}

Averages followed by different column lowercase letters, and different row uppercase letters, are significantly different (Tukey, $\mathrm{p}<0.05)$.

TDN levels did not show significant variation $(\mathrm{P}>0.05)$ between cuttings, both for each cultivar considered singly and when averaging all cultivars.
Across cultivars, however, cv. Star Grass and Quicuio were superior in this parameter $(65.96 \%$ and $65.94 \%$, respectively) with significantly different 
values $(\mathrm{P}<0.05)$ compared to cv. Roxinha $(63.80 \%)$, although not different from other cultivars. The statistical behavior of net energy for lactation, among cuttings and among cultivars, was similar to TDN (as it was measured through this variable).

Table 6 shows that the lower stratum's TDN levels followed the same tendency as the upper stratum, with cv. Roxinha displaying the lowest $(\mathrm{P}<0.05)$ total digestible nutrient concentration, compared to the other cultivars, that were not significantly different from each other $(\mathrm{P}>0.05)$. Cultivar Roxinha also had the lowest net energy for lactation (1.32 Mcal kg of $\left.\mathrm{DM}^{-1}\right)$, which may be explained by its lower TDN content.

Few studies have compared different grasses and their upper and lower strata. Yet, the TDN values reported by Santos et al. (2008) for cv. Tifton 85 (63.61\%) are similar to those found by this study.

All cultivars achieved TDN contents superior to the $55 \%$ minimum considered necessary for ruminants by the NRC. Thanks to the cut management system, which favors maximum accumulation of soluble carbohydrates in the plant, the values for net energy for lactation were classified as optimum for both the upper and lower strata (COSTA, et al., 2005).

Table 6. DM content, total digestible nutrient (TDN) content and net energy for lactation for the lower stratum of the perennial cultivars, for each cut to which the material was submitted.

\begin{tabular}{lccccc}
\hline \multirow{2}{*}{ Forage } & $1^{\text {st }} \mathrm{cut}$ & $2^{\text {nd }} \mathrm{cut}$ & $3^{\text {rd }} \mathrm{cut}$ & $4^{\text {th }}$ cut & Average \\
\cline { 2 - 6 } & & & DM content, $\%$ & \\
\hline Star Grass & $19.3 \mathrm{~b}$ & $18.6 \mathrm{ab}$ & $22.6 \mathrm{~b}$ & $26.4 \mathrm{ab}$ & $21.7 \mathrm{bc}$ \\
Coast-cross & $21.1 \mathrm{~b}$ & $18.1 \mathrm{ab}$ & $21.7 \mathrm{~b}$ & $24.2 \mathrm{bc}$ & $21.3 \mathrm{bc}$ \\
Tifton 68 & $18.7 \mathrm{~b}$ & $17.0 \mathrm{~b}$ & $22.9 \mathrm{~b}$ & $22.8 \mathrm{c}$ & $20.3 \mathrm{c}$ \\
Tifton 85 & $21.3 \mathrm{~b}$ & $20.4 \mathrm{a}$ & $22.3 \mathrm{~b}$ & $18.8 \mathrm{~d}$ & $20.7 \mathrm{c}$ \\
Jiggs & $25.8 \mathrm{a}$ & $19.4 \mathrm{ab}$ & $27.8 \mathrm{a}$ & $25.8 \mathrm{ab}$ & $24.7 \mathrm{a}$ \\
Roxinha limpogras & $19.3 \mathrm{~b}$ & $19.6 \mathrm{ab}$ & $26.1 \mathrm{a}$ & $27.2 \mathrm{a}$ & $23.7 \mathrm{~b}$ \\
Quicuio & $27.5 \mathrm{a}$ & $19.6 \mathrm{a}$ & $25.8 \mathrm{a}$ & $19.1 \mathrm{~d}$ & $20.5 \mathrm{c}$ \\
Average & $21.8 \mathrm{~A}$ & $18.9 \mathrm{~B}$ & $22.7 \mathrm{~A}$ & $23.5 \mathrm{~A}$ & \\
\hline & & & & \\
Star Grass & $62.62 \mathrm{~b}$ & $60.40 \mathrm{~d}$ & $62.05 \mathrm{ab}$ & $63.58 \mathrm{~b}$ & $62.16 \mathrm{a}$ \\
Coast-cross & $63.30 \mathrm{a}$ & $61.66 \mathrm{c}$ & $61.50 \mathrm{bc}$ & $60.94 \mathrm{~cd}$ & $61.85 \mathrm{ab}$ \\
Tifton 68 & $63.51 \mathrm{a}$ & $63.06 \mathrm{~b}$ & $63.04 \mathrm{a}$ & $60.40 \mathrm{~cd}$ & $62.50 \mathrm{a}$ \\
Tifton 85 & $61.64 \mathrm{c}$ & $62.54 \mathrm{bc}$ & $59.47 \mathrm{~d}$ & $60.62 \mathrm{~cd}$ & $61.07 \mathrm{ab}$ \\
Jiggs & $62.89 \mathrm{~b}$ & $63.03 \mathrm{~b}$ & $63.05 \mathrm{a}$ & $63.08 \mathrm{~b}$ & $63.01 \mathrm{a}$ \\
Roxinha limpogras & $55.35 \mathrm{~d}$ & $62.58 \mathrm{bc}$ & $57.99 \mathrm{e}$ & $60.04 \mathrm{~d}$ & $59.99 \mathrm{~b}$ \\
Quicuio & $64.00 \mathrm{a}$ & $64.70 \mathrm{a}$ & $61.07 \mathrm{c}$ & $65.41 \mathrm{a}$ & $63.79 \mathrm{a}$ \\
Average & $61.90 \mathrm{~A}$ & $62.57 \mathrm{~A}$ & $61.17 \mathrm{~A}$ & $62.01 \mathrm{~A}$ & \\
\hline & & Net Energy for Lactation, Mcal kg of DM & \\
Star Grass & $1.42 \mathrm{~b}$ & $1.36 \mathrm{c}$ & $1.40 \mathrm{ab}$ & $1.44 \mathrm{~b}$ & $1.40 \mathrm{a}$ \\
Coast-cross & $1.43 \mathrm{ab}$ & $1.39 \mathrm{c}$ & $1.39 \mathrm{~b}$ & $1.38 \mathrm{~cd}$ & $1.40 \mathrm{a}$ \\
Tifton 68 & $1.44 \mathrm{a}$ & $1.43 \mathrm{~b}$ & $1.43 \mathrm{a}$ & $1.36 \mathrm{~cd}$ & $1.41 \mathrm{a}$ \\
Tifton 85 & $1.39 \mathrm{c}$ & $1.41 \mathrm{bc}$ & $1.34 \mathrm{~d}$ & $1.37 \mathrm{~cd}$ & $1.38 \mathrm{ab}$ \\
Jiggs & $1.42 \mathrm{~b}$ & $1.42 \mathrm{~b}$ & $1.43 \mathrm{a}$ & $1.43 \mathrm{~b}$ & $1.42 \mathrm{a}$ \\
Roxinha limpogras & $1.23 \mathrm{~d}$ & $1.41 \mathrm{bc}$ & $1.30 \mathrm{~d}$ & $1.35 \mathrm{~d}$ & $1.32 \mathrm{~b}$ \\
Quicuio & $1.45 \mathrm{a}$ & $1.74 \mathrm{a}$ & $1.38 \mathrm{c}$ & $1.49 \mathrm{a}$ & $1.44 \mathrm{a}$ \\
Average & $1.40 \mathrm{~A}$ & $1.41 \mathrm{~A}$ & $1.38 \mathrm{~A}$ & $1.40 \mathrm{~A}$ & \\
\hline
\end{tabular}

Averages followed by different column lowercase letters, and different row uppercase letters, are significantly different between themselves (Tukey, $\mathrm{p}<0.05$ ). 
Consistent with the results on tables 5 and 6 , data on tables 7 and 8 show that cv. Roxinha, which had the lowest TDN levels, also showed the highest $(\mathrm{P}<0.05)$ lignin content in both strata. Table 7 also indicates that $\mathrm{cv}$. Coast-cross had the highest $(\mathrm{P}<0.05)$ hemicellulose levels in the upper stratum (38.58\%), while no significant differences $(\mathrm{P}>0.05)$ were detected between other evaluated cultivars, while cvs. Quicuio and Tifton 68 had the highest concentrations of cellulose in the upper stratum (39.12\% and $38.07 \%$, respectively), with significant differences found in the cellulose content of the upper stratum among cultivars. On the other hand, no significant difference $(\mathrm{P}>0.05)$ was detected among cuttings for any of the fibrous carbohydrates.

According to Taiz and Zeiger (2013), there is a tendency for increasing the lignin fraction and decreasing hemicellulose as the cycle of the plant progresses. However, this response was not found in the current study. In plants with an advanced cycle, the hemicellulose tends to associate with lignin through covalent bonds, rendering difficult solubilization of the forage and reducing its digestibility, justifying the importance of performing the cutting or grazing in the correct timing (NERES et al., 2012).

Table 7. Hemicellulose, cellulose and lignin, in \% of DM, for the upper stratum of the perennial cultivars, for each cut to which the material was submitted.

\begin{tabular}{|c|c|c|c|c|c|}
\hline \multirow{2}{*}{ Forage } & $1^{\text {st }}$ cut & $2^{\text {nd }}$ cut & $3^{\text {rd }}$ cut & $4^{\text {th }}$ cut & Average \\
\hline & \multicolumn{5}{|c|}{ Hemicellulose, $\%$ in the DM } \\
\hline Star Grass & $30.06 \mathrm{bc}$ & $26.75 \mathrm{ab}$ & $25.71 \mathrm{~b}$ & $24.34 \mathrm{~b}$ & $26.72 \mathrm{~b}$ \\
\hline Coast-cross & $42.61 \mathrm{a}$ & $33.87 \mathrm{a}$ & $37.28 \mathrm{a}$ & $40.54 \mathrm{a}$ & $38.58 \mathrm{a}$ \\
\hline Tifton 68 & $26.56 \mathrm{c}$ & $28.27 \mathrm{ab}$ & $27.59 \mathrm{~b}$ & $29.72 \mathrm{ab}$ & $28.04 \mathrm{~b}$ \\
\hline Tifton 85 & $27.22 \mathrm{bc}$ & $26.95 \mathrm{ab}$ & $26.81 \mathrm{~b}$ & $32.09 \mathrm{ab}$ & $28.26 \mathrm{~b}$ \\
\hline Jiggs & $28.30 \mathrm{bc}$ & $28.23 \mathrm{ab}$ & $27.89 \mathrm{~b}$ & $28.55 \mathrm{ab}$ & $28.24 \mathrm{~b}$ \\
\hline Roxinha limpogras & $29.78 \mathrm{bc}$ & $29.63 \mathrm{ab}$ & $27.89 \mathrm{~b}$ & $28.39 \mathrm{ab}$ & $28.92 \mathrm{~b}$ \\
\hline Quicuio & $28.15 \mathrm{bc}$ & $23.30 \mathrm{~b}$ & $27.33 \mathrm{~b}$ & $25.69 \mathrm{~b}$ & $26.12 \mathrm{~b}$ \\
\hline \multirow{2}{*}{ Average } & $30.37 \mathrm{~A}$ & $28.14 \mathrm{~A}$ & $28.64 \mathrm{~A}$ & $29.90 \mathrm{~A}$ & \\
\hline & \multicolumn{5}{|c|}{ Cellulose, $\%$ in the DM } \\
\hline Star Grass & $37.03 \mathrm{a}$ & $31.56 \mathrm{c}$ & $41.30 \mathrm{a}$ & $40.99 \mathrm{a}$ & $37.72 \mathrm{ab}$ \\
\hline Coast-cross & $26.35 \mathrm{~b}$ & $31.68 \mathrm{c}$ & $29.71 \mathrm{c}$ & $27.80 \mathrm{~d}$ & $28.88 \mathrm{~d}$ \\
\hline Tifton 68 & $42.12 \mathrm{a}$ & $33.55 \mathrm{c}$ & $39.07 \mathrm{ab}$ & $37.55 \mathrm{~b}$ & $38.07 \mathrm{a}$ \\
\hline Tifton 85 & $40.40 \mathrm{a}$ & $36.32 \mathrm{~b}$ & $38.07 \mathrm{~b}$ & $32.57 \mathrm{c}$ & $36.84 \mathrm{ab}$ \\
\hline Jiggs & $42.70 \mathrm{a}$ & $38.38 \mathrm{~b}$ & $39.63 \mathrm{a}$ & $38.63 \mathrm{~b}$ & $34.84 \mathrm{c}$ \\
\hline Roxinha limpogras & $40.45 \mathrm{a}$ & $30.32 \mathrm{c}$ & $39.32 \mathrm{a}$ & $35.79 \mathrm{bc}$ & $36.47 \mathrm{~b}$ \\
\hline Quicuio & $37.28 \mathrm{a}$ & $44.02 \mathrm{a}$ & $38.14 \mathrm{ab}$ & $37.04 \mathrm{~b}$ & $39.12 \mathrm{a}$ \\
\hline \multirow[t]{2}{*}{ Average } & $38.05 \mathrm{~A}$ & $35.12 \mathrm{~A}$ & $37.93 \mathrm{~A}$ & $35.76 \mathrm{~A}$ & \\
\hline & \multicolumn{5}{|c|}{ Lignin, $\%$ in the DM } \\
\hline Star Grass & $3.37 \mathrm{c}$ & $4.33 \mathrm{~b}$ & $4.86 \mathrm{~b}$ & $5.55 \mathrm{~b}$ & $4.53 \mathrm{abc}$ \\
\hline Coast-cross & $4.39 \mathrm{bc}$ & $3.16 \mathrm{c}$ & $3.36 \mathrm{~d}$ & $3.64 \mathrm{~d}$ & $3.64 \mathrm{c}$ \\
\hline Tifton 68 & $3.96 \mathrm{c}$ & $3.75 \mathrm{c}$ & $4.49 \mathrm{bc}$ & $4.08 \mathrm{~cd}$ & $4.07 \mathrm{bc}$ \\
\hline Tifton 85 & $4.66 \mathrm{~b}$ & $4.10 \mathrm{~b}$ & $3.87 \mathrm{~d}$ & $4.62 \mathrm{c}$ & $4.31 \mathrm{abc}$ \\
\hline Jiggs & $4.16 \mathrm{bc}$ & $3.74 \mathrm{c}$ & $4.28 \mathrm{c}$ & $3.91 \mathrm{~d}$ & $4.02 \mathrm{bc}$ \\
\hline Roxinha limpogras & $4.91 \mathrm{~b}$ & $6.58 \mathrm{a}$ & $5.32 \mathrm{a}$ & $4.86 \mathrm{c}$ & $5.42 \mathrm{a}$ \\
\hline Quicuio & $5.78 \mathrm{a}$ & $4.11 \mathrm{~b}$ & $4.55 \mathrm{~b}$ & $6.27 \mathrm{a}$ & $5.18 \mathrm{ab}$ \\
\hline Average & $4.46 \mathrm{~A}$ & $4.26 \mathrm{~A}$ & $4.39 \mathrm{~A}$ & $4.70 \mathrm{~A}$ & \\
\hline
\end{tabular}

Averages followed by different column lowercase letters, and different row uppercase letters, are significantly different (Tukey, $\mathrm{p}<0.05)$. 
Overall, cv. Star Grass had the greatest average consumption capacity, as the sum of its fibrous fractions $(\mathrm{NDF}=68.97 \%$ ) was the lowest observed. NDF is directly related to consumption capacity: the smaller the sum of HEM+CEL+LIG, the greater the animal consumption capacity will be (VAN SOEST, 1994).

Similar to the upper stratum, the lower stratum of cv. Quicuio (table 8) had the highest $(\mathrm{P}<0.05)$ levels of lignin (6.61\%). However, from all the cultivars that were evaluated, it also generated the greatest concentration of the hemicellulose fraction. Consequently, its cellulose content was the lowest $(27.69 \%)$, significantly different $(\mathrm{P}<0.05)$ when compared to other cultivars. Lignin is indigestible, and therefore has negative effects on the forage (BARBERO et al., 2010). Cellulose content varied between $26.24 \%$ and $35.79 \%$, but stayed within the $20-40 \%$ range described by Van Soest (1994).

Digestibility is also negatively affected the higher the ADF content (VAN SOEST, 1994). Thus, cv. Jiggs had the best digestibility properties, with $35.46 \%$ ADF, while cv. Roxinha negatively stood out with $41.21 \%$ ADF.

Higher lignin concentrations were generally observed in the lower stratum of all cultivars than in the upper stratum, consistent with the higher proportion of stems in the lower stratum.

Table 8. Hemicellulose, cellulose and lignin, in \% of DM, for the lower stratum of the perennial cultivars, for each cut to which the material was submitted.

\begin{tabular}{|c|c|c|c|c|c|}
\hline \multirow{2}{*}{ Forage } & $1^{\text {st }}$ cut & $2^{\text {nd }}$ cut & $3^{\text {rd }}$ cut & $4^{\text {th }}$ cut & Average \\
\hline & \multicolumn{5}{|c|}{ Hemicellulose, $\%$ in the DM } \\
\hline Star Grass & $34.99 \mathrm{abc}$ & $29.86 \mathrm{c}$ & $38.03 \mathrm{a}$ & $38.98 \mathrm{a}$ & $35.46 \mathrm{bc}$ \\
\hline Coast-cross & $41.11 \mathrm{a}$ & $34.44 \mathrm{bc}$ & $35.24 \mathrm{ab}$ & $36.58 \mathrm{ab}$ & $36.84 \mathrm{abc}$ \\
\hline Tifton 68 & $40.37 \mathrm{a}$ & $32.78 \mathrm{bc}$ & 39.69 a & $33.51 \mathrm{c}$ & $36.59 \mathrm{abc}$ \\
\hline Tifton 85 & $39.89 \mathrm{ab}$ & $34.76 \mathrm{bc}$ & $33.99 \mathrm{ab}$ & $35.71 \mathrm{abc}$ & $36.09 \mathrm{abc}$ \\
\hline Jiggs & $40.59 \mathrm{a}$ & $37.89 \mathrm{ab}$ & $37.26 \mathrm{a}$ & $37.28 \mathrm{ab}$ & $38.27 \mathrm{ab}$ \\
\hline Roxinha limpogras & $28.22 \mathrm{c}$ & $38.90 \mathrm{ab}$ & $30.82 \mathrm{~b}$ & $34.32 \mathrm{abc}$ & $33.06 \mathrm{c}$ \\
\hline Quicuio & $40.56 \mathrm{a}$ & $42.32 \mathrm{a}$ & $37.44 \mathrm{a}$ & $41.68 \mathrm{a}$ & $40.50 \mathrm{a}$ \\
\hline \multirow[t]{2}{*}{ Average } & $37.96 \mathrm{~A}$ & $35.85 \mathrm{~A}$ & $36.07 \mathrm{~A}$ & $36.86 \mathrm{~A}$ & \\
\hline & \multicolumn{5}{|c|}{ Cellulose, $\%$ in the DM } \\
\hline Star Grass & $31.05 \mathrm{~b}$ & $34.68 \mathrm{a}$ & $33.09 \mathrm{ab}$ & $29.99 \mathrm{~b}$ & $32.20 \mathrm{ab}$ \\
\hline Coast-cross & $30.08 \mathrm{~b}$ & $31.64 \mathrm{a}$ & $32.62 \mathrm{ab}$ & $33.85 \mathrm{a}$ & $32.05 \mathrm{ab}$ \\
\hline Tifton 68 & $29.77 \mathrm{~b}$ & $30.61 \mathrm{ab}$ & $31.49 \mathrm{ab}$ & $35.14 \mathrm{a}$ & $31.75 \mathrm{abc}$ \\
\hline Tifton 85 & $32.80 \mathrm{~b}$ & $32.37 \mathrm{a}$ & $35.38 \mathrm{a}$ & $34.29 \mathrm{a}$ & $33.71 \mathrm{ab}$ \\
\hline Jiggs & $31.29 \mathrm{~b}$ & $30.75 \mathrm{ab}$ & $29.91 \mathrm{~b}$ & $31.10 \mathrm{~b}$ & $30.76 \mathrm{bc}$ \\
\hline Roxinha limpogras & $41.19 \mathrm{a}$ & $30.07 \mathrm{~b}$ & $35.79 \mathrm{a}$ & $34.68 \mathrm{a}$ & $35.43 \mathrm{a}$ \\
\hline Quicuio & $26.24 \mathrm{c}$ & $26.98 \mathrm{c}$ & $30.84 \mathrm{~b}$ & $26.69 \mathrm{~b}$ & $27.69 \mathrm{c}$ \\
\hline \multirow[t]{2}{*}{ Average } & $31.77 \mathrm{~A}$ & $31.01 \mathrm{~A}$ & $32.73 \mathrm{~A}$ & $32.25 \mathrm{~A}$ & \\
\hline & \multicolumn{5}{|c|}{ Lignin, $\%$ in the DM } \\
\hline Star Grass & $4.98 \mathrm{bc}$ & $4.52 \mathrm{bc}$ & $3.76 \mathrm{~d}$ & $4.67 \mathrm{ab}$ & $4.48 \mathrm{c}$ \\
\hline Coast-cross & $4.98 \mathrm{bc}$ & $5.76 \mathrm{~b}$ & $5.01 \mathrm{c}$ & $4.58 \mathrm{ab}$ & $5.08 \mathrm{bc}$ \\
\hline Tifton 68 & $5.00 \mathrm{bc}$ & $4.79 \mathrm{bc}$ & $3.95 \mathrm{~d}$ & $4.06 \mathrm{~b}$ & $4.45 \mathrm{c}$ \\
\hline Tifton 85 & $4.64 \mathrm{c}$ & $3.77 \mathrm{c}$ & $5.17 \mathrm{c}$ & $4.60 \mathrm{ab}$ & $4.54 \mathrm{bc}$ \\
\hline Jiggs & $4.36 \mathrm{c}$ & $4.69 \mathrm{bc}$ & $5.51 \mathrm{bc}$ & $4.26 \mathrm{ab}$ & $4.70 \mathrm{bc}$ \\
\hline Roxinha limpogras & $5.23 \mathrm{bc}$ & $6.02 \mathrm{a}$ & $6.85 \mathrm{ab}$ & $5.04 \mathrm{a}$ & $5.78 \mathrm{ab}$ \\
\hline Quicuio & $7.57 \mathrm{a}$ & $6.10 \mathrm{a}$ & $7.40 \mathrm{a}$ & $5.36 \mathrm{a}$ & $6.61 \mathrm{a}$ \\
\hline Average & $5.25 \mathrm{~A}$ & $5.09 \mathrm{~A}$ & $5.38 \mathrm{~A}$ & $4.65 \mathrm{~A}$ & \\
\hline
\end{tabular}

Averages followed by different column lowercase letters, and different row uppercase letters, are significantly different (Tukey, $\mathrm{p}<0.05)$. 


\section{Conclusion}

In this study, cultivars Jiggs and Tifton 68 appeared as the most adequate cultivars for a continuous management system of four cuts, with good chemical composition and the greatest accumulation of dry biomass, while cv. Quicuio had the lowest production response in this system.

\section{Acknowledgements}

We are grateful to Coordenação de Aperfeiçoamento de Pessoal de Nível Superior - CAPES for the fellowship that made this work possible, granted between 2012 and 2014.

\section{References}

ASSOCIATION OF OFFICIAL ANALYTICAL CHEMISTS - AOAC. Official methods of analysis. $16^{\text {th }}$ ed. Arlington: Washington, D.C.: 1995. 2000 p.

BARBERO, L. M.; CECATO, U.; LUGÃO, S. M.; GOMES, J. A.; LIMÃO, V. A.; ABRAHÃO, J. J.; ROMA, C. F. Produção animal e valor nutritivo da forragem de pastagem de coastcross consorciada com amendoim forrageiro. Arquivos Brasileiros de Medicina Veterinária e Zootecnia, Belo Horizonte, v. 62, n. 3, p. 645-653, 2010.

BARCELLOS, A. de O.; RAMOS, A. K. B.; VILELA, L.; MARTHA JUNIOR, G. B. Sustentabilidade da produção animal baseada em pastagens consorciadas e no emprego de leguminosas exclusivas, na forma de banco de proteína, nos trópicos brasileiros. Revista Brasileira de Zootecnia, Viçosa, MG, v. 37, p. 51-67, 2008. Número Especial.

BENINCASA, M. M. P. Análise de crescimento de plantas. 2. ed. Jaboticabal: FUNEP, 2003. 41 p.

BIRCHAM, J. S. Herbage growth and utilization under continuous stocking management. 1981. Thesis ( $\mathrm{PhD}$ in animal science) - University of Edinburgh, Edinburgh.

BOLSEN, K. K.; ASHBELL, G.; WEINBERG, Z. G. Silage fermentation and silage additives-Review. AsianAustralasian Journal of Animal Sciences, Seoul, v. 9, n. 5, p. 483-494, 1996.

BURTON, G. W.; MONSON, W. G. Registration of Tifton 68 bermudagrass. Crop Science, Madison, v. 24, n.6, p. 1211-1219, 1993.
CARVALHO, M. S. S. Desempenho agronômico e análise de crescimento de capins do gênero Cynodon em resposta à frequência de corte. 2011. Dissertação (Mestrado em Animal Science and Pastures) - Escola Superior de Agricultura Luiz de Queiroz, Piracicaba.

COMISSÃO DE QUÍMICA E FERTILIDADE DO SOLO - CQFS RS/SC. Manual de adubação e calagem para os Estados do Rio Grande do Sul e de Santa Catarina. UNIUBE: Uberaba, 2004. v. 10.

COSTA, M. A. L.; VALADARES FILHO, S. D. C.; VALADARES, R. F. D.; PAULINO, M. F.; CECON, P. R.; PAULINO, P. V. R.; PAIXÃO, M. L. Validação das equações do NRC (2001) para predição do valor energético de alimentos nas condições brasileiras. Revista Brasileira de Zootecnia, Viçosa, MG, v. 34, n. 1, p. 280-287, 2005.

GOERING, H. K.; VAN SOEST, P. J. Forage fiber analysis: apparatus reagents, procedures and some applications. Agricultural Handbook, Beltsville, v. 379, p. 1-20, 1970.

MOE, P. W.; TYRREL, H. F. Estimating metabolizable and net energy of feeds. In: INTERNATIONAL SYMPOSIUM ON FEED COMPOSITION, ANIMAL NUTRIENT REQUIREMENTS, AND COMPUTERIZATION OF DIETS, 1., 1976, Logan. Proceedings... Logan: Utah State University, 1976. p. 232-237.

NERES, M. A.; CASTAGNARA, D. D.; SILVA, F. B.; OLIVEIRA, P. S. R. D.; MESQUITA, E. E.; BERNARDI, T. C.; VOGT, A. S. L. Características produtivas, estruturais e bromatológicas dos capins Tifton 85 e Piatã e do feijão-guandu cv. Super N, em cultivo singular ou em associação. Ciência Rural, Santa Maria, v. 42, n. 5, p. 862-869, 2012.

PEDREIRA, C. G. S.; SILVA, S. C. da. Acúmulo de forragem durante a rebrotação de capim-xaraés submetido a três estratégias de desfolhação. Revista Brasileira de Zootecnia, Viçosa, MG, v. 38, n. 4, p. 618-625, 2009.

POTT, C. A.; MÜLlER, M. M. L.; BERTELLI, P. B. Adubação verde como alternativa agroecológica para recuperação da fertilidade do solo. Revista Ambiência, Guarapuava, v. 3, n. 2, p. 51-63, 2007.

SANTOS, N. L.; SILVA, M. W. R. da; CHAVES, M. A. Efeito da irrigação suplementar sobre a produção dos capins tifton 85 , tanzânia e marandu no período de verão no sudoeste baiano. Ciência Animal Brasileira, Goiânia, v. 9, n. 4, p. 911-922, 2008.

SAS INSTITUTE. SAS Language reference. Version 6. Cary: SAS Institute, 1993. 1042 p. 
SILVA, F. R. D.; GAIL, V. F.; MOREIRA, G. M. Matéria seca e proteína bruta da grama Jiggs em diferentes alturas e épocas de corte. Cultivando o Saber, Cascavel, v. 4, n. 4, p. 48-54, 2011.

SOARES FILHO, C. V.; RODRIGUES, L. R. A.; PERRIL, S. H. Produção e valor nutritivo de dez gramíneas forrageiras na região Noroeste do Estado de São Paulo. Acta Scientiarum, Maringá, v. 24, n. 5, p. 1377-1384, 2002.
TAIZ, L.; ZEIGER, E. Fisiologia vegetal. 5. ed. Porto Alegre: Artmed, 2013. 918 p.

VAN SOEST, P. J. Nutritional ecology of the ruminant. $2^{\text {th }}$ ed. Corvallis: O \& B Books, 1994. 415 p.

VAN SOEST, P. J.; ROBERTTSON, J. B.; LEWIS, B. A. Methods for dietary fiber, neutral detergent fiber and non starch polysaccharides in relation to animal nutrition. Journal of Dairy Science, Champaign, v. 74, n. 10, p. 3583-3597, 1991. 